\title{
PENGARUH SISTEM AKUNTANSI KEUANGAN, TEKNOLOGI INFORMASI DAN KOMITMEN ORGANISASI TERHADAP KINERJA SATUAN KERJA PERANGKAT DAERAH (SKPD) DI LINGKUNGAN PEMERINTAH KABUPATEN TEBO
}

\author{
Eva Setiarini Damanik ${ }^{1}$
}

\begin{abstract}
The purpose of this study is to examine the influence of financial accounting system, information technology and organizational commitment on the performance of SKPD. The independent variables of this study were financial accounting system, information technology and organizational commitment, moreover, the dependent variable was the performance of SKPD. This study was conducted by taking a sample of head on regional working units, financial administration officials, and the financial staff at the local government unit in the Tebo district administration office. The hypothesis empirically tested using multiple linear regression analysis. Statistical test results showed that the financial accounting system, information technology and organizational commitment simultaneously affect the performance of SKPD. Financial accounting system and organizational commitment partially positive and significant impact on the performance of SKPD, moreover information technology does not significantly influence of the performance of SKPD.

Keywords: financial accounting system, information technology, organizational commitment, performance of SKPD.
\end{abstract}

\section{PENDAHULUAN}

Otonomi daerah merupakan upaya pemberdayaan daerah dalam pengambilan keputusan daerah berkaitan dengan pengelolaan sumber daya yang dimiliki. Dengan pemberian otonomi daerah, pengelolaan keuangan sepenuhnya berada di tangan pemerintah daerah. Setiap SKPD harus membuat laporan keuangan unit kerja. Kepala SKPD selaku Pengguna Anggaran harus menyelenggarakan akuntansi atas transaksi keuangan, aset, utang, dan ekuitas dana, termasuk transaksi pendapatan dan belanja.

Permendagri No. 13 Tahun 2006 yang telah direvisi dengan Permendagri No. 59 Tahun 2007 tentang Pedoman Pengelolaan Keuangan Daerah merupakan implementasi paradigma baru yang berorientasi pada prestasi kinerja diterapkan dalam penyusunan APBD, sistem akuntansi dan pengelolaan keuangan daerah. Untuk itu, setiap pemerintah daerah harus dapat mempersiapkan sumber daya manusia yang benar-benar memahami dan melaksanakan sistem akuntansi keuangan pemerintah daerah untuk melakukan pengelolaan keuangan daerah sesuai peraturan yang telah ditetapkan. Untuk memudahkan pelaksanaan pembukuan, diperkenankan menggunakan software aplikasi, konsekuensinya SDM harus mampu dan mahir dalam mengoperasikan komputer serta memahami aplikasi prosedur penatausahaan keuangan daerah. Berdasarkan hal tersebut maka penatausahaan keuangan daerah mutlak diperlukan sumber daya manusia yang professional di bidang teknologi informasi khususnya yang berkaitan dengan pengelolaan keuangan daerah.

Balitbangda Jambi bekerjasama dengan LSI melakukan survei terhadap

${ }^{1}$ STIE Graha Karya Muara Bulian 
SKPD Pemerintah Kabupaten di Provinsi Jambi. Hasilnya, Kabupaten Tebo merupakan salah satu dari lima kabupaten yang mendapatkan rapor merah dalam hal pelayanan kepada masyarakat (http://jambi.tribunnews.com). DPRD Kabupaten Tebo juga menyoroti masih lemahnya penyerapan anggaran di beberapa SKPD, terbukti masih terdapat SILPA sebesar Rp. 76 milyar (8,92\%) pada tahun 2013. Dengan adanya SILPA ini menunjukkan bahwa kinerja belum maksimal, SKPD tidak mampu menyerap dan melaksanakan anggaran yang telah dialokasikan karena masih rendahnya komitmen untuk melaksanakan kegiatan sesuai dengan anggaran yang telah ditetapkan.

Penelitian ini merupakan pengembangan dari penelitian terdahulu Sukmana dan Anggarsari (2009) yang meneliti tentang pengaruh sistem akuntansi keuangan terhadap kinerja satuan kerja perangkat daerah, yang dilengkapi oleh Nasir dan Oktari (2010) mengenai teknologi informasi serta Anurti (2013) tentang komitmen organisasi.

Berdasarkan latar belakang yang telah diuraikan diatas, penulis ingin menguji pengaruh sistem akuntansi keuangan, teknologi informasi dan komitmen organisasi terhadap kinerja SKPD.

\section{KAJIAN PUSTAKA}

Sistem akuntansi keuangan daerah yaitu serangkaian secara sistematik dari prosedur, penyelenggara, peralatan, dan elemen lain untuk mewujudkan fungsi akuntansi sejak analisis sampai dengan pelaporan keuangan di lingkungan organisasi pemerintah (Sukmana, 2009). Prosedur yang dimaksud dimulai dari pencatatan, penggolongan, dan peringkasan transaksi dan/atau kejadian keuangan serta pelaporan keuangan dalam rangka pertanggungjawaban pelaksanaan APBD yang berkaitan dengan pengeluaran pemerintah daerah. Sistem akuntansi SKPD dilaksanakan oleh PPK-SKPD. Kegiatan akuntansi pada satuan kerja meliputi prosedur akuntansi penerimaan kas, prosedur akuntansi pengeluaran kas, prosedur akuntansi aset tetap, dan prosedur akuntansi selain kas (Silalahi, 2012).

Teknologi informasi meliputi komputer (mainframe, mini, micro), perangkat lunak (software), database, jaringan (internet, intranet), electronic commerce, dan jenis lainnya yang berhubungan dengan teknologi (Mustafa, dkk., 2010). Pemanfaatan teknologi informasi yang tepat dan didukung oleh keahlian personil yang mengoperasikannya dapat meningkatkan kinerja organisasi/perusahaan maupun kinerja individu yang bersangkutan (Nasir \& Oktari, 2010). Berdasarkan hal tersebut, dapat dikatakan bahwa teknologi informasi ini sangat mempengaruhi kinerja, dimana teknologi informasi ini diperlukan untuk mengolah data yang diperoleh melalui sistem pengumpulan data yang akan menghasilkan data laporan mingguan, bulanan, triwulan serta laporan tahunan dan teknologi informasi juga mempengaruhi kinerja yang dilihat dari ketersediaan perangkat teknologi informasi dan kemutakhirannya.

Komitmen organisasi adalah suatu tingkat keyakinan seorang karyawan memihak pada suatu organisasi tertentu yang tujuannya berniat memelihara/mempertahankan keanggotaan dalam organisasi itu (Anurti, 2013). Komitmen berarti keinginan karyawan (pegawai) untuk tetap mempertahankan keanggotaannya dalam organisasi dan bersedia melakukan usaha yang tinggi bagi pencapaian tujuan organisasi (Darmawan, 2013). Variabel ini dapat diukur dengan indikator kemauan karyawan, kesetiaan karyawan, dan 
kebanggaan karyawan. Dengan kata lain komitmen organisasi menyiratkan hubungan pegawai dengan organisasi secara aktif. Karena pegawai yang menunjukkan komitmen tinggi memiliki keinginan untuk memberikan tenaga dan tanggung jawab yang lebih dalam menyokong kesejahteraan dan keberhasilan organisasi tempatnya bekerja.

Kinerja (performance) adalah gambaran mengenai tingkat pencapaian pelaksanaan suatu kegiatan atau program atau kebijakan dalam mewujudkan sasaran, tujuan, misi, visi organisasi yang tertuang dalam strategic planning suatu organisasi (Sibagariang, 2013). Dalam konteks organisasi pemerintah daerah pengukuran kinerja SKPD dilakukan untuk menilai seberapa baik SKPD tersebut melakukan tugas pokok dan fungsi yang dilimpahkan kepadanya selama periode tertentu. Pengukuran kinerja SKPD merupakan wujud dari vertical accountability dan horizontal accounntability.

\section{KERANGKA PEMIKIRAN}

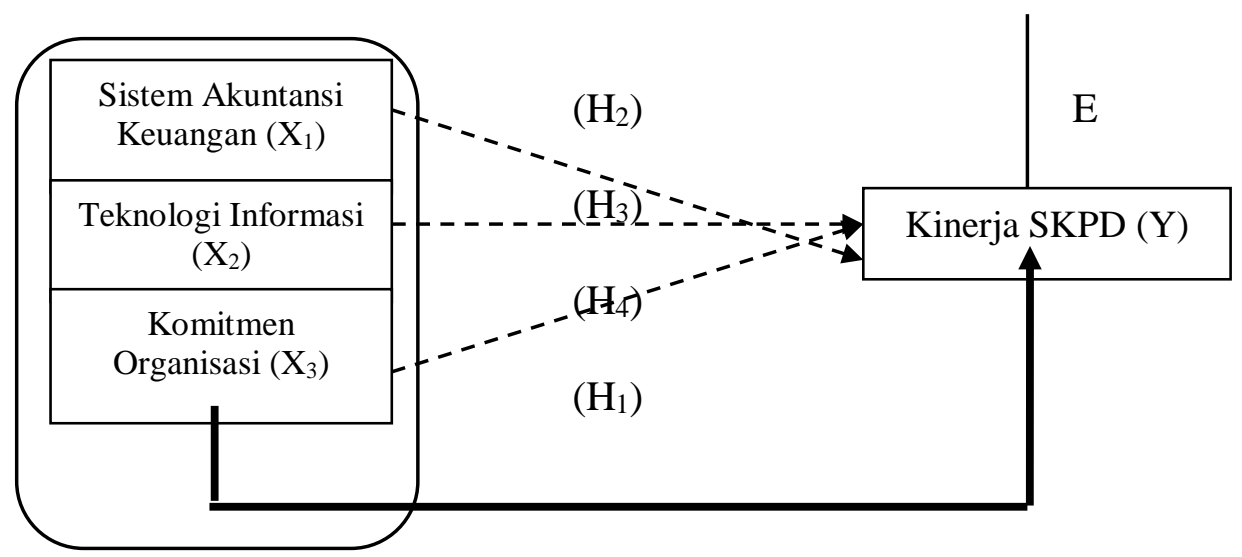

Keterangan :

Pengaruh secara simultan

Pengaruh secara parsial

\section{Hubungan Sistem Akuntansi Keuangan dengan Kinerja SKPD}

Menurut Mahsun, dkk. (2006) sistem akuntansi keuangan daerah merupakan aktivitas jasa untuk menyediakan informasi yang diperlukan untuk pengambilan keputusan pada sektor publik, pengambilan keputusan terkait dengan keputusan baik pada sektor ekonomi, sosial dan politik. Hariyanto dalam Sukmana (2009) menyatakan sistem akuntansi keuangan daerah yaitu serangkaian secara sistematik dari prosedur, penyelenggara, peralatan, dan elemen lain untuk mewujudkan fungsi akuntansi sejak analisis sampai dengan pelaporan keuangan di lingkungan organisasi pemerintah. Dalam pengelolaan keuangan daerah, pemerintah memerlukan suatu sistem akuntansi keuangan untuk pengelolaan dana dalam rangka pertanggungjawaban pelaksanaan APBD. Dengan menggunakan sistem akuntansi keuangan akan menghasilkan laporan keuangan yang baik, laporan keuangan yang baik merupakan salah satu indikator bahwa organisasi tersebut memiliki kinerja yang baik pula. Oleh karena itu, dapat disimpulkan bahwa semakin baik sistem akuntansi keuangan yang diterapkan organisasi 
maka semakin baik pula kinerja organisasi.

\section{Hubungan Teknologi Informasi dengan Kinerja SKPD}

Menurut Mustafa, dkk (2010), teknologi informasi meliputi komputer, perangkat lunak, database, jaringan, electronic commerce, dan jenis lainnya yang berhubungan dengan teknologi. Pemanfaatan teknologi informasi yang tepat didukung dengan keahlian personil yang mengoperasikannya dapat meningkatkan kinerja organisasi/perusahaan maupun kinerja individu yang bersangkutan (Nasir \& Oktari, 2010). Berdasarkan hal tersebut, dapat dikatakan bahwa teknologi informasi ini sangat mempengaruhi kinerja, dimana teknologi informasi ini diperlukan untuk mengolah data yang diperoleh melalui sistem pengumpulan data yang akan menghasilkan data laporan. Sehingga dapat disimpulkan bahwa semakin tinggi teknologi informasi yang digunakan maka akan semakin tinggi pula kinerja organisasi.

\section{Hubungan Komitmen Organisasi dengan Kinerja SKPD}

Menurut Robbins dalam Anurti (2013) komitmen organisasi adalah suatu tingkat keyakinan seorang karyawan memihak pada suatu organisasi tertentu yang tujuannya berniat memelihara/mempertahankan keanggotaan dalam organisasi itu. Porter, et.al dalam Darmawan (2013) mendefinisikan komitmen sebagai kuatnya pengenalan dan keterlibatan seseorang dalam suatu organisasi tertentu. Seorang pegawai/karyawan diharapkan memiliki kepercayaan yang kuat dan menerima nilai-nilai dan tujuan dari organisasi, mempunyai kemauan yang kuat untuk berusaha dan bekerja keras untuk mencapai target organisasi, dan keinginan untuk tetap menjadi bagian dari organisasi. Sehingga jika seorang karyawan memegang prinsip atau komitmen organisasi, maka hal ini akan mendongkrak kinerja organisasi tersebut. Maka disimpulkan bahwa semakin tinggi seorang karyawan memegang komitmen organisasi maka akan semakin tinggi pula kinerja organisasi tersebut.

\section{Hipotesis}

$\mathrm{H}_{1}$ : Sistem akuntansi keuangan, teknologi informasi, dan komitmen organisasi secara simultan berpengaruh terhadap kinerja SKPD.

$\mathrm{H}_{2}$ : Sistem akuntansi keuangan berpengaruh terhadap kinerja SKPD.

$\mathrm{H}_{3}$ : Teknologi informasi berpengaruh terhadap kinerja SKPD.

$\mathrm{H}_{4}$ : Komitmen organisasi berpengaruh terhadap kinerja SKPD.

\section{METODE PENELITIAN}

Populasi dalam penelitian ini adalah Kepala SKPD/Kuasa Pengguna Anggaran, PPK-SKPD, dan staf bagian keuangan karena mereka dianggap mengetahui kebijakan organisasi, pengambil kebijakan, pelaksana dan bertanggungjawab terhadap kinerja keuangan pada SKPD masing-masing. Oleh karena itu, total populasi yang akan diberi kuesioner adalah sebanyak 90 responden.

Dengan mempertimbangkan sedikitnya jumlah populasi, maka penulis berinisiatif untuk menjadikan seluruh populasi tersebut sebagai sampel yakni 90 responden. Hal ini seperti yang dikemukakan oleh Arikunto bahwa jika jumlah populasi penelitian kurang dari 100 orang, maka sebaiknya diambil semuanya sebagai sampel atau responden penelitian. 
Alat pengumpulan data dilakukan dengan menggunakan lembaran kuesioner secara langsung kepada responden. Dalam kuesioner ini terdapat pertanyaan tentang variabel sistem akuntansi keuangan, teknologi informasi, komitmen organisasi dan kinerja SKPD. Masing-masing pertanyaan akan diberikan sejumlah alternatif jawaban. Skala pengukuran yang digunakan dalam penelitian ini adalah Skala Likert, sebagaimana yang dinyatakan oleh Ghozali (2005) skala yang sering dipakai dalam penyusunan kuesioner adalah skala ordinal dalam bentuk skala Likert yang berisi lima tingkat preferensi jawaban. Pada penelitian ini untuk mentransformasi data ordinal menjadi data interval penulis menggunakan bantuan program MSI.

Analisis data dalam penelitian ini menggunakan pendekatan regresi linier berganda. Analisis regresi berganda digunakan untuk menguji pengaruh sistem akuntansi keuangan, teknologi informasi dan komitmen organisasi terhadap kinerja SKPD di lingkungan pemerintah Kabupaten Tebo. Metode ini menggunakan bantuan program SPSS. Model analisa regresi linier berganda dalam penelitian ini dapat dirumuskan sebagai berikut :

$$
\mathbf{Y}=\mathbf{a}+\mathbf{b}_{1} \mathbf{X}_{1}+\mathbf{b}_{2} \mathbf{X}_{2}+\mathbf{b}_{3} \mathbf{X}_{3}+\mathbf{e}
$$

Keterangan :

$\begin{array}{ll}\mathrm{Y} & =\text { Kinerja SKPD } \\ \mathrm{a} & =\text { Konstansta } \\ \mathrm{b}_{1}, \mathrm{~b}_{2}, \mathrm{~b}_{3} & =\text { Koefisien regresi } \\ \mathrm{X}_{1} & =\text { Sistem akuntansi keuangan } \\ \mathrm{X}_{2} & =\text { Teknologi informasi } \\ \mathrm{X}_{3} & =\text { Komitmen organisasi } \\ \mathrm{e} & =\text { Error }\end{array}$

\section{Uji Kualitas Data}

\section{HASIL PEMBAHASAN}

Berdasarkan hasil uji validitas variabel $\mathrm{X}_{1}, \mathrm{X}_{2}, \mathrm{X}_{3}$, dan variabel $\mathrm{Y}$, r-hitung $>0,206$, dan semua item pertanyaan dinyatakan valid, sehingga pertanyaan di setiap item dianggap bisa mengukur variabel yang akan diteliti.

Berdasarkan dari hasil uji reliabilitas diatas, semua variabel yang dijadikan instrumen dalam penelitian ini dinyatakan reliable karena menunjukkan tingkat reliabilitas yang tinggi hal ini dibuktikan nilai koefisien alpha $>0,6$ sehingga dapat digunakan sebagai alat pengukur yang dapat dihandalkan atau dipercaya.

\section{Analisis Regresi Berganda}

Analisis ini untuk mengetahui arah hubungan antara variabel independen dengan variabel dependen apakah positif atau negatif dan untuk memprediksi nilai dari variabel dependen apabila nilai variabel independen mengalami kenaikan atau penurunan. Dalam penelitian ini, analisis regresi berganda digunakan untuk menguji pengaruh Sistem Akuntansi Keuangan $\left(\mathrm{X}_{1}\right)$, Teknologi Informasi $\left(\mathrm{X}_{2}\right)$ dan Komitmen Organisasi $\left(\mathrm{X}_{3}\right)$ terhadap Kinerja SKPD, dengan persaman regresi sebagai berikut :

$$
Y=1,154+0,273 X_{1}-0,042 X_{2}+0,409 X_{3}
$$


Berdasarkan persamaan regresi berganda diatas dapat diinterpretasikan sebagai berikut :

1. Konstanta sebesar 1,154 memberikan arti bahwa apabila sistem akuntansi keuangan $\left(\mathrm{X}_{1}\right)$, teknologi informasi $\left(\mathrm{X}_{2}\right)$ dan komitmen organisasi $\left(\mathrm{X}_{3}\right)$ diasumsikan $=0$, maka kinerja SKPD $(\mathrm{Y})$ secara konstan bernilai 1,154.

2. Koefisien regresi variabel sistem akuntansi keuangan $\left(X_{1}\right)$ sebesar 0,273 memberikan arti bahwa peningkatan sistem akuntansi keuangan dapat mendorong peningkatan kinerja SKPD dengan asumsi variabel teknologi informasi $\left(\mathrm{X}_{2}\right)$ dan komitmen organisasi $\left(\mathrm{X}_{3}\right)$ konstan.

3. Koefisien regresi variabel teknologi informasi $\left(\mathrm{X}_{2}\right)$ sebesar $-0,042$ memberikan arti bahwa peningkatan teknologi informasi dapat mendorong penurunan kinerja SKPD dengan asumsi variabel sistem akuntansi keuangan $\left(\mathrm{X}_{1}\right)$ dan komitmen organisasi $\left(\mathrm{X}_{3}\right)$ konstan.

4. Koefisien regresi variabel komitmen organisasi $\left(X_{3}\right)$ sebesar 0,409 memberikan arti bahwa peningkatan komitmen organisasi dapat mendorong peningkatan kinerja SKPD dengan asumsi variabel sistem akuntansi keuangan $\left(\mathrm{X}_{1}\right)$ dan teknologi informasi $\left(\mathrm{X}_{2}\right)$ konstan.

\section{Hasil Uji Signifikansi Simultan (Uji-F)}

Uji signifikan simultan dilakukan untuk menguji apakah terdapat pengaruh yang signifikan antara sistem akuntansi keuangan, teknologi informasi dan komitmen organisasi terhadap kinerja SKPD secara simultan, melalui uji-F. Hasil yang ditunjukkan dari pengolahan data menghasilkan nilai F-hitung 21,046 > Ftabel 2,71 dengan signifikansi $0,000<0,05$, maka Hipotesis $1\left(\mathrm{H}_{1}\right)$ diterima. Sehingga dapat disimpulkan bahwa variabel sistem akuntansi keuangan, teknologi informasi dan komitmen organisasi secara simultan berpengaruh signifikan terhadap terhadap kinerja SKPD. Jika sistem akuntansi keuangan, teknologi informasi dan komitmen organisasi secara bersama-sama meningkat, maka kinerja SKPD juga akan meningkat.

\section{Uji Signifikansi Parsial (Uji-t)}

Tabel Hasil Uji Parsial

\begin{tabular}{lcc}
\hline \multicolumn{1}{c}{ Variabel } & t hitung & signifikansi \\
\hline Sistem Akuntansi Keuangan & 4,322 & 0,000 \\
$\left(\mathrm{X}_{1}\right)$ & & \\
Teknologi Informasi $\left(\mathrm{X}_{2}\right)$ & $-0,474$ & 0,637 \\
Komitmen Organisasi $\left(\mathrm{X}_{3}\right)$ & 5,183 & 0,000 \\
\hline
\end{tabular}

Hasil yang ditunjukkan dari tabel diatas dapat dilihat variabel $\mathrm{X}_{1}$ menghasilkan nilai t-hitung 4,322 > t-tabel 1,662 dengan signifikansi 0,000. Hasil perhitungan tersebut menunjukkan bahwa sistem akuntansi keuangan berpengaruh terhadap kinerja SKPD secara parsial. Hal ini dibuktikan dengan tingkat signifikansi $<0,05$. Dengan demikian Hipotesis $2\left(\mathrm{H}_{2}\right)$ diterima. Variabel $\mathrm{X}_{2}$ menunjukkan t-hitung -0,474 < t-tabel 1,662 dengan signifikansi 0,637. Hasil uji-t menunjukkan bahwa teknologi informasi berpengaruh negatif dan tidak signifikan terhadap kinerja SKPD secara parsial. Hal ini dibuktikan dengan tingkat signifikansi yang diperoleh $>0,05$. Dengan demikian Hipotesis $3\left(\mathrm{H}_{3}\right)$ ditolak. Variabel $\mathrm{X}_{3}$ menunjukkan nilai t-hitung 5,183 > t-tabel 1,662 dengan signifikansi 0,000. Hasil uji-t menunjukkan bahwa komitmen organisasi berpengaruh positif 
dan signifikan terhadap kinerja SKPD secara parsial hal ini dibuktikan dengan tingkat signifikansi $<0,05$. Dengan demikian hipotesis $4\left(\mathrm{H}_{4}\right)$ diterima.

\section{Koefisien Determinasi}

Dari hasil pengolahan data, dapat diketahui bahwa nilai koefisien determinasi dari pengaruh variabel sistem akuntansi keuangan, teknologi informasi, dan komitmen organisasi terhadap kinerja SKPD adalah sebedar 42,6\%. Nilai koefisien determinasi atau $\mathrm{R}$ square yang diperoleh sebesar 0,426 yang menunjukkan bahwa kinerja SKPD yang ada dilingkungan Pemerintah Kabupaten Tebo dipengaruhi oleh variabel sistem akuntansi keuangan, teknologi informasi, dan komitmen organisasi sebesar 42,6\%, dan sisanya 57,4\% dipengaruhi oleh variabel lain yang belum diteliti dalam penelitian ini.

\section{Hasil Uji Asumsi Klasik}

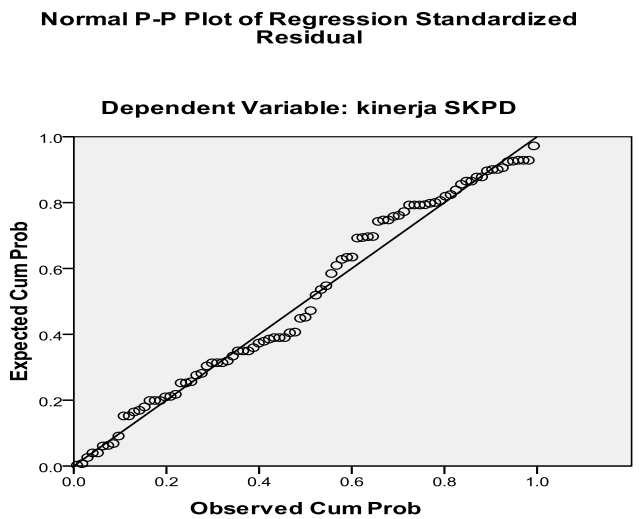

Gambar Uji Normalitas

Berdasarkan gambar diatas diketahui bahwa data menyebar di sekitar garis diagonal dan mengikuti arah garis diagonal, maka model regresi memenuhi asumsi normalitas.

Tabel Uji Multikolinearitas

\begin{tabular}{lcc}
\hline \multicolumn{1}{c}{ Variabel } & Nilai Tolerance & Nilai VIF \\
\hline Sistem Akuntansi Keuangan & 0,699 & 1,430 \\
Teknologi Informasi & 0,565 & 1,769 \\
Komitmen Organisasi & 0,778 & 1,286 \\
\hline
\end{tabular}

Berdasarkan tabel, model regresi yang diajukan untuk variabel independen semuanya terbebas dari multikolinearitas ini terlihat dari hasil pengolahan data yang menunjukkan variabel independen memiliki nilai VIF $<10$ dan Tolerance $>$ 0,1 sehingga dapat disimpulkan bahwa variabel independen ini dapat digunakan untuk mengetahui pengaruhnya terhadap kinerja SKPD. 
Scatterplot

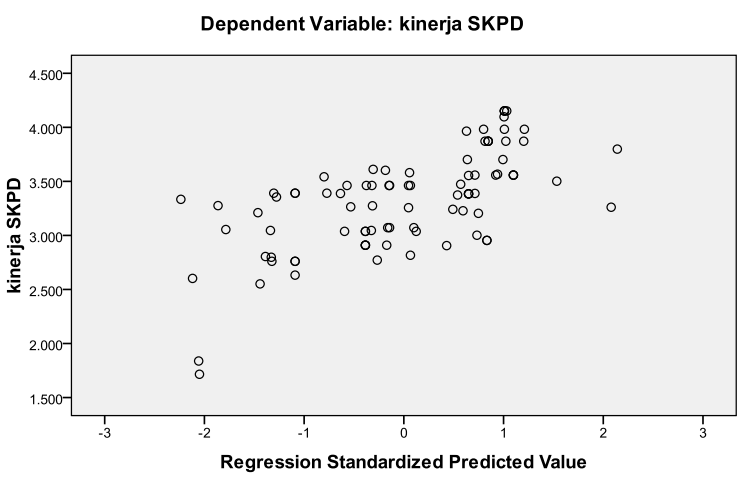

Gambar Diagram Scatterplot

Berdasarkan diagram scatterplot diatas, data tersebar secara acak tanpa membentuk suatu pola tertentu, serta titik-titiknya menyebar diatas dan dibawah 0 pada sumbu Y, ini membuktikan tidak terjadi heteroskedasitas. Dengan demikian dapat disimpulkan bahwa dalam model regresi ini terdapat perbedaan varians dari residual dari suatu pengamatan ke pengamatan yang lain.

\section{PEMBAHASAN}

Pengaruh Simultan Sistem Akuntansi Keuangan, Teknologi Informasi, dan Komitmen Organisasi Terhadap Kinerja SKPD

Berdasarkan uji simultan yang telah dilakukan terhadap variabel sistem akuntansi keuangan $\left(\mathrm{X}_{1}\right)$, teknologi informasi $\left(\mathrm{X}_{2}\right)$, dan komitmen organisasi $\left(\mathrm{X}_{3}\right)$ terhadap kinerja SKPD (Y) dilingkungan Pemerintah Kabupaten Tebo menunjukkan hasil F-hitung 21,046 > F-tabel 2,71 dengan tingkat signifikansi $0,000<0.05$ yang menunjukkan nilai yang signifikan. Hal tersebut berarti, sistem akuntansi keuangan, teknologi informasi, dan komitmen organisasi jika diregresikan bersama akan berpengaruh positf dan signifikan terhadap kinerja SKPD.

Penelitian ini menunjukkan bahwa ketika sistem akuntansi keuangan, teknologi informasi, dan komitmen organisasi dilaksanakan secara serentak, maka kinerja SKPD akan menunjukan nilai yang cukup tinggi, dengan kata lain signifikan. Hal ini sesuai dengan penelitian yang dilakukan oleh Sukmana dan Anggarsari (2009), serta Anurti (2013) yang menunjukkan hasil yang signifikan atas variabel sistem akuntansi keuangan, teknologi informasi, dan komitmen organisasi jika diregresikan bersama terhadap kinerja SKPD.

Kinerja SKPD didukung oleh baiknya sistem akuntansi keuangan, teknologi informasi, dan komitmen organisasi. SKPD Kabupaten Tebo, dalam penelitian ini menunjukkan ketika sistem akuntansi keuangan, teknologi informasi, dan komitmen organisasi dilaksanakan secara serentak, maka kinerja SKPD akan menunjukkan nilai yang cukup tinggi, dengan kata lain penerapan sistem akuntansi keuangan, teknologi informasi, dan komitmen organisasi yang maksimal berpengaruh pada semakin baiknya kinerja SKPD yang ditunjukkan oleh instansi pemerintah, dalam hal ini SKPD di lingkungan Kabupaten Tebo. 


\section{Pengaruh Sistem Akuntansi Keuangan Terhadap Kinerja SKPD}

Berdasarkan hasil uji parsial yang telah dilakukan antara sistem akuntansi keuangan sebagai variabel $\mathrm{X}_{1}$ terhadap kinerja SKPD sebagai variabel $\mathrm{Y}$ menunjukkan bahwa t-hitung 4,322 > t-tabel 1,662 dengan nilai signifikansi sebesar $0,000<0,05$ menunjukkan bahwa variabel sistem akuntansi keuangan berpengaruh signifikan terhadap kinerja SKPD, sehingga dapat dipahami bahwa salah satu usaha yang dapat ditempuh untuk meningkatkan kinerja SKPD dilingkungan Pemerintah Kabupaten Tebo adalah dengan cara meningkatkan sistem akuntansi keuangan.

Interpretasi dari kesimpulan tersebut adalah ketika sistem akuntansi keuangan yang dilakukan semakin baik, maka kinerja SKPD juga akan semakin meningkat. Hal ini ditunjukkan dengan tingkat signifikansi yang lebih kecil dari 0,05 . Hasil penelitian ini sejalan dengan penelitian yang dilakukan oleh Tuasikal (2007), Sukmana \& Anggarsari (2009) serta Silalahi (2012). Dengan menggunakan sistem akuntansi keuangan akan menghasilkan laporan keuangan yang baik, laporan keuangan yang baik merupakan salah satu indikator bahwa organisasi tersebut memiliki kinerja yang baik pula. Oleh karena itu, dapat disimpulkan bahwa semakin baik sistem akuntansi keuangan yang diterapkan organisasi maka semakin baik pula kinerja organisasi.

\section{Pengaruh Teknologi Informasi Terhadap Kinerja SKPD}

Hasil analisis regresi berganda menunjukkan bahwa teknologi informasi sebagai variabel $\mathrm{X}_{2}$ tidak berpengaruh terhadap kinerja SKPD sebagai variabel $\mathrm{Y}$. Hal ini ditunjukkan dengan nilai t-hitung $-0,474<$ t-tabel 1,662 dengan tingkat signifikansi 0,637>0,05 menunjukkan bahwa variabel teknologi informasi tidak berpengaruh signifikan terhadap kinerja SKPD. Hal ini berarti bahwa semakin tinggi teknologi informasi, maka kinerja SKPD cenderung akan menurun. Hasil penelitian yang tidak signifikan ini diantaranya disebabkan oleh tidak atau belum mampu dimanfaatkannya teknologi informasi secara optimal dalam hubungannya dengan kinerja SKPD, rendahnya penerimaan terhadap teknologi informasi dan belum adanya integrasi teknologi informasi pada pelaksanaan tugas-tugas SKPD di lingkungan Pemerintah Kabupaten Tebo. Penelitian ini berbeda dengan hasil penelitian yang dilakukan oleh Nadir (2011) yang menyatakan bahwa pemanfaatan teknologi informasi berpengaruh signifikan terhadap kinerja unit pemerintah. Namun hal ini dapat diterima karena dari pengumpulan kuesioner dan wawancara dengan pejabat dan staf SKPD, ternyata pemanfaatan teknologi informasi baru dalam tahap awal atau tahap persiapan. Selain itu, kurangnya pendidikan dan pelatihan serta bimbingan teknis pemanfaatan teknologi informasi di bidang akuntansi keuangan dan pengelolaan keuangan daerah dapat menjadi salah satu penyebab tidak berpengaruhnya teknologi informasi terhadap kinerja SKPD di Kabupaten Tebo.

Hasil penelitian ini sejalan dengan penelitian Nasir dan Oktari (2010) yang menemukan bukti bahwa teknologi informasi tidak berpengaruh terhadap kinerja instansi pemerintah. Hal ini terjadi karena pada dasarnya teknologi informasi hanyalah sebuah alat yang tetap memerlukan peran manusia untuk menjalankannya. Optimal atau tidaknya penggunaan teknologi informasi dalam penyelesaian pekerjaan bergantung pada kemampuan sumber daya manusia yang mengoperasikannya. Hal ini dapat dilakukan dengan memberikan programprogram pendidikan dan pelatihan (Diklat) / bimbingan teknis (Bintek) kepada 
staf/pegawai pengelola keuangan pada masing-masing SKPD serta mempertimbangkan kesesuaian latar belakang pendidikan pegawai. Selain itu, teknologi informasi harus dimanfaatkan secara optimal dengan cara meningkatkan penerimaan dan kemampuan staf/pegawai pengelola keuangan terhadap penggunaan teknologi informasi.

\section{Pengaruh Komitmen Organisasi Terhadap Kinerja SKPD}

Berdasarkan hasil uji parsial yang telah dilakukan antara komitmen organisasi sebagai variabel $\mathrm{X}_{3}$ terhadap kinerja SKPD sebagai variabel $\mathrm{Y}$ menunjukkan bahwa t-hitung 5,183 > t-tabel 1,662 dan nilai signifikansi 0,000< 0,05 , maka terdapat pengaruh yang signifikan komitmen organisasi terhadap kinerja SKPD dilingkungan pemerintah Kabupaten Tebo, sehingga dapat dipahami bahwa untuk meningkatkan kinerja SKPD pemerintah Kabupaten Tebosalah satunya adalah dengan cara meningkatkan komitmen organisasi dari masing-masing SKPD yang ada dilingkungan pemerintah Kabupaten Tebo. Penelitian ini sejalan dengan penelitian yang dilakukan oleh Anurti (2013) yang menemukan bukti bahwa komitmen organisasi berpengaruh signifikan posistif terhadap kinerja SKPD, namun penelitian ini tidak sejalan dengan Mufarrohah, dkk (2013) yang menemukan bukti bahwa komitmen organisasi berpengaruh negatif terhadap kinerja SKPD.

Berdasarkan hasil observasi terhadap komitmen organisasi ditinjau dari kemauan untuk bekerja dalam mencapai tujuan organisasi menunjukkan tingkat yang cukup baik. Hal ini disebabkan karena para pegawai sudah memahami tugastugas tersebut dan merupakan kewajiban tanggung jawabnya sesuai dengan uraian tugas yang telah ditetapkan sehingga kemampuan, kemauan dan hasrat untuk mewujudkan tujuan organisasi oleh seluruh Pegawai Negeri Sipil di lingkungan Pemerintah Kabupaten Tebo secara umum sudah cukup baik, ini dapat dilihat dari besarnya pengaruh komitmen organisasi terhadap kinerja SKPD sebesar 0,483 atau $48,3 \%$.

\section{Simpulan}

\section{SIMPULAN DAN SARAN}

Secara simultan, sistem akuntansi keuangan, teknologi informasi, dan komitmen organisasi berpengaruh signifikan terhadap kinerja SKPD. Secara parsial, sistem akuntansi keuangan dan komitmen organisasi berpengaruh signifikan terhadap kinerja SKPD. Sedangkan teknologi informasi tidak berpengaruh signifikan terhadap kinerja SKPD.

\section{Saran}

1. Bagi pemerintah Kabupaten Tebo hendaknya mengoptimalkan pemanfaatan teknologi informasi dengan cara meningkatkan penerimaan dan kemampuan pegawai terhadap penggunaan teknologi informasi.

2. Bagi peneliti selanjutnya yang tertarik untuk meneliti masalah yang sama, dianjurkan meneliti pada subjek yang lain, dengan variabel-variabel lain yang berpengaruh terhadap kinerja SKPD dan bisa mengambil sampel yang lebih luas. 


\section{DAFTAR PUSTAKA}

Anurti, S.W., 2013. Pengaruh Peran Manajer Pengelolaan Anggaran dan Komitmen Organisasi terhadap Kinerja SKPD (studi empiris pada SKPD di Kota Padang). Jurnal Universitas Negeri Padang.

Darmawan, D. 2013. Prinsip-Prinsip Perilaku Organisasi. Surabaya : Pena Semesta.

Ghozali, I. 2005. Aplikasi Analisis Multivariate dengan Program SPSS. Edisi 3. Semarang : Badan Penerbit Undip.

Halim, A., Restianto, Y.E. \& Karman, I.W. 2010. Sistem Akuntansi Sektor Publik. Yogyakarta : UPP STIM YKPN.

Halim, A. \& Iqbal, M. 2012. Pengelolaan Keuangan Daerah. Yogyakarta : UPP STIM YKPN.

Mahsun, M., Firma, S., Heribertus, A.P. 2006. Akuntansi Sektor Publik. Yogyakarta : BPFE.

Mufarrohah., Sutrisno T \& Purnomosdhi, B. 2013. Pengaruh Budaya Organisasi, Komitmen Organisasi, Gaya Kepemimpinan, dan Kompetensi terhadap Kinerja Pemerintahan Daerah (studi empiris pada Kabupaten Bangkalan). Jurnal InFestasi. Vol. 9 No. 2 Desember 2013. Hal. 123 - 136.

Mustafa, S., Sutrisno \& Rosidi. 2010. Analisis Faktor-Faktor yang berpengaruh terhadap Keterandalan dan Ketepatwaktuan Pelaporan Keuangan pada SKPD Pemerintah Daerah Kota Kendari. Jurnal Universitas Haaluoleo, Kendari.

Nasir, A \& Oktari, R. 2010. Pengaruh Pemanfaatan Teknologi Informasi dan Pengendalian Intern terhadap Kinerja Instansi Pemerintah (studi pada Satuan Kerja Perangkat Daerah Kabupaten Kampar). http:/lejournal.unri.ac.id/index.php/JE/article

Republik Indonesia. Peraturan Menteri Dalam Negeri (Permendagri) Nomor 13 Tahun 2006 Tentang Pedoman Pengelolaan Keuangan Daerah.

Republik Indonesia. Peraturan Menteri Dalam Negeri (Permendagri) Nomor 59 Tahun 2007 Tentang Perubahan Atas Peraturan Menteri Dalam Negeri (Permendagri) Nomor 13 Tahun 2006.

Riduwan \& Akdon. 2007. Rumus dan Data dalam Analisis Statistik. Bandung : Alfabeta.

Sibagariang, A. 2013. Pengaruh Kualitas Sumber Daya Manusia, Komunikasi, Sarana Pendukung dan Komitmen Organisasi terhadap Kinerja SKPD (studi empiris pada Pemerintah Kota Sibolga). Jurnal Universitas Negeri Padang, Maret 2013..

Silalahi, S.P. 2012. Pengaruh Anggaran Berbasis Kinerja, Sistem Akuntansi Keuangan Daerah, dan Sistem Informasi Pengelolaan Keuangan Daerah terhadap Penilaian Satuan Kerja Perangkat Daerah (studi Pemerintahan di Kota Dumai). Jurnal Ekonomi, Volume 20, Nomor 3, September 2012.

Sugiyono. 2013. Metode Penelitian Kuantitatif, Kualitatif dan $R \& D$. Bandung : Penerbit Alfabeta.

Sujianto, A.E. 2009. Aplikasi Statistik dengan SPSS. Jakarta: Prestasi Pustaka.

Sukmana, W. \& Anggarsari, L. 2009. Pengaruh Pengawasan Intern dan Pelaksanaan Sistem Akuntansi Keuangan Daerah terhadap Kinerja Pemerintah Daerah (survei pada Satuan Kerja Perangkat Daerah Kota Tasikmalaya). Jurnal Akuntansi FE Unsil, Vol. 4, No. 1, 2009. 
Sunjoyo., Setiawan, R., Carolina, V., Magdalena, N. \& Kurniawan, A. 2013. Aplikasi SPSS untuk Smart Riset (Program IBM SPSS 21.00). Bandung : Alfabeta.

Tuasikal, A. 2007. Pengaruh Pemahaman Sistem Akuntansi Pengelolaan Keuangan Daerah terhadap Kinerja Satuan Kerja Pemerintah Daerah (studi pada Kab. Maluku Tengah di Provinsi Maluku). Jurnal Akuntansi Keuangan dan Sektor Publik. Vol. 08. No. 1. Februari 2007.

http://jambi.tribunnews.com/2013/09/20/rapor-lima-kabupaten-di-jambi-merah http://www.bungoteboekspres.com/berita-dewan-soroti-kinerja-skpd---.html 